\title{
KEPEMIMPINAN TRANFORMATIF KEPALA SEKOLAH DALAM MEWUJUDKAN PROFESIONALITAS MANAJEMEN MADRASAH (Studi Kasus Madrasah Aliyah Darul Ulum Kota Semarang)
}

TRANSFORMATIVE LEADERSHIP OF MADRASAH HEAD IN REALIZING THE PROFESSIONALISM OF MANAGEMENT MADRASAH

(Case Study of Senior High School Darul Ulum Semarang City)

\author{
Elen Inderasari, Nur Hadi \\ Pascasarjana IAIN Surakarta \\ email: inderasari85iain@gmail.com \\ email: azarinesaufa312@gmail.com
}

\begin{abstract}
The era of disruption requires leaders who are brave, critical, and innovative in responding to the challenges of the times. The leader of the era of disruption must have a strong leadership character. The objectives to be achieved in the discussion are to find out the transformative leadership of the principal in realizing the professionalism of teachers in madrasah; and management optimization in realizing teacher professionalism in madrasah through transformative leadership at MA Darul Ulum Semarang City. This writing method is a qualitative research with a case study approach. The research data uses primary data derived from interviews and observations as well as secondary data from documents. Sources of data in this study are in the form of words and actions, the rest are additional data such as documents and others. The transformative leadership style applied at MA Darul Ulum Semarang City adopted the leadership model of Ki Hajar Dewantara with the motto Ing Ngarsa Sung Tuladha, Ing Madya Mangun Karsa, Tut Wuri Handayani. The leadership management of the MA Darul Ulum Semarang City principal in optimizing teacher professionalism includes planning, organizing, coordinating, and controlling. Leadership behavior in an effort to implement leadership skills plays a very important role in improving school quality. Positive leadership behavior is very supportive of the application of principal management and will achieve more success.
\end{abstract}

Keywords: management; professionality; transformative leadership

Abstrak
Era disrupsi dibutuhkan pemimpin yang berani bersikap, kritis, dan inovatif
dalam menjawab tantangan zaman. Pemimpin era disrupsi harus memiliki
karakter kepemimpinan yang kuat. Tujuan yang hendak dicapai dalam
pembahasan, yaitu untuk mengetahui kepemimpinan tranformatif kepala
madrasah dalam mewujudkan profesionalitas guru di madrasah; dan
manajemen optimalisasi dalam mewujudkan profesionalitas guru di


madrasah melalui kepemimpinan transformatif di MA Darul Ulum Kota Semarang. Metode penulisan ini penelitian kualitatif pola pendekatan studi kasus. Data penelitian menggunakan data primer yang berasal dari hasil interview dan observasi serta data sekunder yang berasal dari dokumen. Sumber data dalam penelitian ini berwujud kata dan tindakan selebihnya adalah data tambahan seperti dokumen dan lain-lain. Gaya pemimpinan transformatif yang diterapkan di MA Darul Ulum Kota Semarang mengadopsi model kepemimpinan Ki Hajar Dewantara dengan semboyannya Ing Ngarsa Sung Tuladha, Ing Madya Mangun Karsa, Tut Wuri Handayani. Manajemen kepemimpinan kepala sekolah MA Darul Ulum Kota Semarang dalam mengoptimalkan profesionalitas guru meliputi perencanaan (planning), pengorganisasian (organizing), koordinasi (coordinating), dan pengawasan (controlling). Perilaku kepemimpinan dalam upaya melaksanakan keterampilan memimpin memegang peranan yang sangat penting untuk untuk meningkatkan kualitas sekolah. Perilaku kepemimpinan yang positif sangat mendukung terhadap penerapan manajemen kepala sekolah akan lebih mencapai keberhasilan.

Kata kunci: manajemen; profesionalitas; kepemimpinan tranformatif

\section{PENDAHULUAN}

Era disrupsi merupakan istilah untuk keadaan yang sebenarnya terjadi sebagai akibat dari perubahan keadaan industri berawal dari perkembangan teknologi informasi yang telah berubah begitu secara cepat. Di era ini dukungan kekuatan teknologi informasi mempunyai dampak yang sangat besar terhadap pola perkembangan industri dalam menjawab tantangan zaman. Pemimpin era disrupsi harus memiliki karakter kepemimpinan yang kuat. Namun, pada kenyataannya, bahwa tidak semua orang yang mampu menduduki jabatan pemimpin memiliki kemampuan untuk memimpin atau memiliki 'kepemimpinan' yang cukup baik, sebaliknya banyak orang yang memiliki bakat kepemimpinan tetapi terkadang tidak pernah mendapat kesempatan untuk menjadi pemimpin dalam arti yang sebenarnya. Menurut (Bush \& Coleman, 2012: 12) pengertian kata 'kepala' hanya menunjukan segi formal dari jabatan pemimpin semata. Maksudnya, secara telaah yuridisformal setiap orang dapat saja diangkat sebagai kepala suatu usaha atau bagian (berdasarkan surat keputusan atau surat pengangkatan). Dibutuhkan pemimpin yang ideal yang mampu walaupun belum tentu bahwa orang yang bersangkutan memiliki kemampuan menggerakan mempengaruhi dan membimbing bawahannya serta (memimpin) memiliki kemampuan melaksanakan tugas-tugas untuk mencapai sebuah tujuan (Badeni, 2014: $6)$.

Madrasah sebagai bagian integral dalam proses pembangunan sumber daya manusia yang berkualitas seutuhnya harus memiliki mutu pendidikan yang baik. Pembangunan mutu pendidikan akan terus dilakukan secara baik oleh pemerintah maupun pihak berbagai madrasah sebagai 
penyelenggara utama pendidikan dalam usaha memenuhi kebutuhan dan tuntutan masyarakat terhadap mutu pendidikan, sekaligus sebagai respon terhadap perubahan kehidupan yang begitu sangat cepat di era globalisasi dewasa ini. Dengan sederet harapan mutu lulusan pendidikan dapat bersaing dalam pemenuhan kebutuhan kerja pangsa pasar dan memberikan kesejahteraan bagi keluarga dan masyarakat di sekitarnya. Berbagai kenyataan terhadap rendahnya mutu madrasah dipengaruhi oleh beragam faktor, salah satunya adalah manajemen pendidikan. Sejalan dengan Hadis dan Nurhayati (dalam Fadhli, 2017) yang mengemukakan bahwa secara perspektif makro terdapat banyak faktor yang mempengaruhi mutu pendidikan yang saah satunya adalah faktor manajemen pendidikan yang dilaksanakan secara profesional. Oleh karena itu, lembaga pendidikan perlu berpikir apa saja halhal penting yang harus dikelola dengan baik. Sehingga tidak terjadi mismanagement, dalam arti tidak tersebar pada khusus hal-hal kecil yang tidak substantif bahkan cenderung kurang berdampak positif terhadap upaya peningkatan mutu. Kepemimpinan gaya transformasional di lingkungan lembaga pendidikan Islam harus memberikan spirit dan mendorong terwujudnya kelembagaan yang berkualitas dan bermutu (Aminuddin, 2017; Nengsih, Gusfira, \& Pratama, 2020).

Asumsi mendasari pada model pola kepemimpinan transformatif dengan memulai segala sesuatunya dengan membuat terbentuknya visi dan misi yang jelas, memberi pengalaman segi intelektual yang mampu memberi berbagai inspirasi pada bawahannya, memberi ide-ide cermerlang dan inovatif yang baru serta solusi yang kreatif. Kepemimpinan transformasional berupaya dalam meningkatkan kesadaran para pengikutnya dengan menarik cita-cita dan nilai-nilai seperti keadilan (justice), kedamaian (peace) dan persamaan (equality) (Komsiyah, 2016: 304). Kepemimpinan transformatif terjadi saat salah satu atau beberapa orang melibatkan diri dengan yang lain (Lestari, 2017: 42).

Model kepemimpinan transformatif secara khusus berhubungan dengan segala sesuatu berupa gagasan perbaikan. Menurut (Wayne \& Miskel, 2014: 2) pemimpin transformatif berniat mengubah budayabudaya dan strategi-strategi sebuah organisasi demi tujuan kemajuan. Pada umumnya pola pemimpin transformatif berusaha untuk mengubah status quo dalam lembaga yang dipimpin dan mewujudkan suatu visi, dengan cara mengejawatkan visi pada bawahannya dan menanamkan nilai-nilai yang dapat membawa perubahan ke arah pengembangan pada bawahan dan organisasi atau lembaga pendidikan. Perubahan yang dibawa oleh kepemimpinan transformatif yaitu mencakup berbagai aspek pendukung, misalnya pola kerja, sikap dan keahlian. Dengan demikian, gaya pemimpin transformatif harus berjuang untuk mampu mempengaruhi perubahan dengan cara yang benar tentunya perubahan bukanlah asal berubah, tapi 
tujuannya menghasilkan kinerja manjadikan madrasah yang lebih baik.

$$
\text { Perkembangan penelitian }
$$

terkait menajemen kepemimpinan sudah banyak penelitian dalam usaha perbaikan atas manajemen pemimpin yang ideal. Berbagai artikel yang telah diterbitkan salah satunya tentang The Evolution Of Management Thought yang ditulis oleh $\mathrm{Ni}$ Made Suci Universitas Ganesa, dalam Jurnal Manajemen dan Bisnis Vol. 1 No.1, Tahun 2019 menyampaikan evolusi terkaid pemikiran dalam managemmen kepemimpinan di pengaruhi tokoh Daniel A. Wren \& Arthur G. Bedeian hadirnya konsep Total Kualitas Management (TQM) W. Edwards Deming (1900-1993) and Joseph Juran (1904), dalam pemikiran ilmu manajemen merupakan pertanda era moderen di abad ke-20. Deming termasuk orang Amerika yang tinggal di Jepang dianggap sebagai PakarKontrol Kualitas, Total Quality Management (TQM) memfokuskan pada bagaimana mengembangkan kualitas melalui suatu organisasi. Manajemen sistem informasi menyediakan informasi mengenai organisasi terkait perkembangan pemikiran manajemen terbaru dalam kaitannya dengan era globalisasi, teknologi dan informasi (Suci, 2019: 24).

Peningkatan kebijakan daya saing pendidikan erat kaitannya dengan membangun Sumber Daya Manusia (SDM) (Agus Purwowidodo, Saifudin Zuhri, 2020: 311). Dari berbagai dasar pertimbangan beberapa penelitian yang terkait dengan perlunya gaya kepemimpinan yang tepat untuk mendukung keberhasilan manajemen SDM suatu organisasi, maka peningkatan mutu madrasah menjadi suatu keniscayaan yaitu perlunya dilakukan optimalisasi pengembangan budaya mutu madrasah yang harus dilakukan oleh kepala madrasah sebagai pemimpin tertinggi yang sangat berpengaruh bahkan sangat menentukan mutu madrasah (Karim, 2010). Namun, fenomena ini tidak seperti yang terjadi di MA Darul Ulum Kota Semarang. Berdasarkan hasil wawancara yang dilakukan kepada pengelolaan madrasah dilakukan oleh kepala madrasah (oleh Arif Hidayatullah, M.Ag, menjabat sejak berdirinya madrasah mulai tahun 2006-2017) masih mengandalkan tenaga "seadanya" (tidak mempertimbangkan linieritas keahlian akademik yang terpenting bisa dan mau mengajar, tidak membuat Renstra, RPS, hadir tidak memenuhi peraturan yang ada, dan lain-lain), hanya berbekal "ikhlas" (yang rela digaji dengan paspasan sehingga bagi pendidik tidak dituntut keterlibatannya secara optimal dalam membawa kemajuan madrasah), dan "pasrah" (yang terpenting peserta didik di akhir tahun pelajaran lulus tidak harus mempertimbangkan nilai yang merupakan syarat mutlak untuk bisa masuk ke jenjang selanjutnya, yang terpenting pembelajaran tetap berlangsung walaupun dengan cara konvensional, dan lain-lain), oleh karenanya, MA Darul Ulum Kota Semarang berjalan stagnan. Artinya, hanya sebatas melakukan "ritualitas" pendidikan tanpa melalukan upaya pemberdayaan madrasah ke depan yang permasalahannya semakin kompleks 
dan persaingan semakin berat (karena berdekatan dengan sekolah-sekolah yang jenjangnya sama: SMAN 16, SMA 13, SMAN 8, MA Uswatun Hasanah, MA Nurul Huda, MA Miftahussalam, SMK Palapa, dan SMK Al-Ma'arif NU), sehingga tidak mampu mengimbangi mutu sekolah dan atau madrasah di sekelilingnya baik dalam mutu akademik dan nonakademik.

Berbagai permasalahan dari hasil wawancara dan observasi awal nampak berbagai problematika MA Darul Ulum Kota Semarang. Namun, dalam hal ini penulis lebih fokus pada upaya peningkatan profesionalitas guru melalui kepemimpinan transformatif yang dilakukan oleh kepala madrasah. Peningkatan profesionalitas guru perlu dilakukan dengan tujuan mampu meningkatkan kualitas layanan pendidikan dan mampu bersaing atau mengimbangi sekolah dan atau madrasah di sekeliling. Salah satu solusinya adalah menerapkan kepemimpinan transformatif untuk membawa ke arah profesionalitas guru dengan cara melakukan; bimbingan, mendorong, mengarahkan, menggerakkan pendidik, karyawan, peserta didik, orang tua, dan masyarakat untuk sama-sama memiliki madrasah.

Alasan mengangkat judul ini karena kepemimpinan transformatif merupakan kepemimpinan yang mengutamakan pemberian kesempatan dan mendorong semua warga madrasah untuk bersedia tanpa paksaan, berpartisipasi aktif dalam rangka mencapai tujuan madrasah (Badeni, 2014: 36) di satu sisi dengan cara pelatihan, seminar, TOT, dan banyak hal pembaharuan dalam mengikuti kemajuan media pembelajaran berbasis IT. Membangun profesionalitas guru dapat dilakukan dengan membina komunikasi dan kerjasama dengan wali murid secara baik dan dilakukan secara periodik terjadwal guna menjawab kebutuhan yang sifatnya cepat disikapi baik oleh sekolah dan oleh orang tua siswa.

Berdasarkan uraian tersebut, penerapan manajemen kepemimpinan transformatif sangat berpengaruh besar terhadap perkembangan kualitas baikburuknya suatu madrasah. Dengan demikian, penulis tertarik menelaah gaya kepemimpinan tranformatif kepala madrasah dalam mewujudkan profesionalitas guru di madrasah dan upaya optimalisasi dalam mewujudkan profesionalitas guru di madrasah melalui kepemimpinan transformatif di MA Darul Ulum Kota Semarang.

\section{METODOLOGI}

Desain penelitian dalam tulisan ini termasuk jenis penelitian kualitatif dengan pendekatan pada studi kasus. Data yang digunakan berupa penggunaan data primer yang berasal dari hasil interview kepada para guru dan kepala sekolah dan observasi serta data sekunder yang berasal dari dokumen. Sumber data dalam penelitian ini adalah kata-kata dan tindakan terkait gaya kepemimpinan trasformatif kepala sekolah selebihnya adalah data tambahan seperti dokumen dan lainlain. Sumber data yang menjadi informan atau narasumber adalah subjek penelitan yaitu kepala madrasah, guru, 
tenaga kependidikan, staff, tukang kebun, satpam sekolah, tenaga perpustakaan, siswa,wali murid, komite madrasah, dan lain-lain MA Darul Ulum Kota Semarang. Teknik pengumpulan data menggunakan: 1) wawancara, yaitu mengajukan pertanyaan-pertanyaan yang relevan tentang kepemimpinan transformative terhadap informan yang dipilih dengan pertanyaan terbuka, sehingga informasi yang diperoleh semakin lengkap dan mendalam, yang berkaitan dengan masalah yang diteliti; 2) observasi, yaitu dengan melakukan pengamatan secara langsung terhadap manajemen gaya kepemimpinan transformatif kepala sekolah/ madrasah di MA Darul Ulum Kota Semarang; 3) dokumentasi, mencatat arsip maupun dokumen yang berkaitan dengan manajemen peningktan mutu pembelajaran. Teknik analisis data menggunakan bentuk analisa kualitatif. Proses analisisa data menggunakan teknik analisis data model interaktif (interactive model of analysis) yang terdiri dari empat komponen analisa data, yaitu pada prinsip penyelenggaraan kepemimpinan trasformatif dengan langkah pengumpulan data, reduksi data, penyajian data dan penarikan kesimpulan. Proses keempat komponen tersebut merupakan siklus, dimana proses pengumpulan data, reduksi data, penyajian data dan penarikan kesimpulan itu merupakan rangkaian kegiatan analisis secara berurutan dan saling terkait ( Miles \& Huberman dalam Muhammad, Aan, \& Khomsun, 2015).

\section{HASIL DAN PEMBAHASAN}

Kepemimpinan Tranformatif Kepala Madrasah Dalam Mewujudkan Profesionalitas Guru Di Madrasah

Kepala madrasah sering disebut sebagai pemimpin lembaga memegang peran penting dalam upaya membangun budaya mutu di madrasah oleh karenanya kepala madrasah harus mampu menggunakan kepemimpinannya secara optimal. Menurut Muslim (2018), kepemimpinan transformatif adalah sebuah gaya kepemimpinan madrasah yang di dalamnya mengandung suatu proses dari pimpinan dan para bawahannya yang memiliki usaha untuk memajukan madrasah dalam hal moralitas dan motivasi.

Menurut Lau Sue dan Glover Derek (dalam Hermino, 2014: 13) gaya adalah bentuk cara dan pola yang digunakan oleh seseorang dalam melaksanakan berbagai kegiatan atau berperilaku. Sebagaimana firman Allah Swt dalam Surat Al-A'raf ayat 129 sebagai berikut.

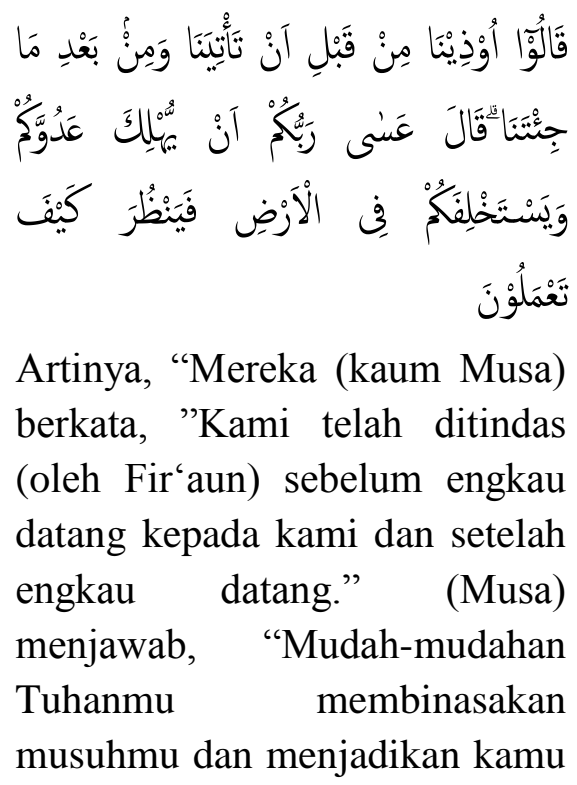


khalifah di bumi; maka Dia akan melihat bagaimana perbuatanmu." (Q.S. AlA'raf:129).

Ayat di atas menjelaskan bahwa sebagai pemimpin harus mampu melindungi dan merangkul semua bawahan yang ada dan harus dapat menjauhi sikap semena-mena (otoriter) yang membuat staf tidak nyaman untuk melaksanakan tugasnya (bekerja) secara maksimal. Oleh karenanya, sebagai pemimpin harus mampu merangkut dan memotivasi staf untuk bekerja bukan karena terpaksa dan atau takut kepada pimpinan tetapi karena kesadaran akan tugasnya, sehingga ke depannya akan mampu memberi kebermanfaatan (kemaslahatan) bagi kemajuan lembaga.

Menurut (Bush \& Coleman, 2012: 130) ada beberapa ciri kepemimpinan transformatif yaitu: (1) pemimpin memiliki sifat keteladanan baik perilaku dan ucapan yang ditunjukkan pada pengikutnya; (2) pemimpin mengajak pengikutnya untuk mengerjakan tugas dengan cara baru, memberi apresiasi terhadap gagasan pengikutnya; (3) pemimpin memperhatikan kebutuhan akan kebutuhan karyawannya agar maju dan berkembang dalam kariernya; dan (4) sebagai pemimpin memberikan motivasi, mengajak karyawan bekerja lebih baik untuk mewujudkan cita-cita bersama.

Ciri-ciri tersebut pada akhirnya akan memunculkan inovasi-inovasi terutama bagi pendidik dalam upaya meningkatkan mutu madrasah, antara lain: (1) berusaha memberi contoh perilaku inovatif; (2) memberi rangsangan intelektual anak buah; (3) mengundang pendidik dan karyawan berbagi pengetahuan yang bermanfaat; (4) memberikan arah visi; (5) memberi konsultasi; (6) mendelegasikan; (7) memberikan umpan balik yang positif; (8) menunjukkan apresiasi pada kinerja inovatif; (9) memberi rewards; (10) memberi dukungan fasilitas; (11) memantau kegiatan inovatif; dan (12) memberi penugasan (Bush \& Coleman, 2012: 134).

Selain itu, pemimpin yang transformatif juga menjadi pelaku dalam perubahan lembaga secara demokratis dan berintegritas yang berorientasikan kepada: (1) melakukan perubahan untuk menentukan kebutuhan; (2) mampu menciptakan visi dan misi; (3) memberi inspirasi kepada para pengikutnuya; (3) memusatkan perhatian pada jangka panjang; (4) mengubah organisasi untuk menampung visi baru; dan (5) membimbing berbagai mitra atau staff untuk memikul tanggung jawab lebih besar bagi perkembangan dirinya maupun orang lain.

Kepemimpinan transformatif MA Darul Ulum Kota Semarang merupakan kepemimpinan yang mengutamakan pemberian kesempatan dan atau mendorong semua unsur pembangun di sekolah (pendidik, staf, peserta didik, orang tua, dan masyarakat) berpartisipasi secara optimal dalam rangka mencapai tujuan pendidikan serta alat pemberdayaan dan pengembangan personal dan cara yang efektif dalam menolong seseorang mengembangkan berbagai potensi dan 
karirnya. Kepemimpinan transformatif ini dalam pandangan MA Darul Ulum Kota Semarang sesuai dengan konsep konvensional luhur Ki Hajar Dewantara adalah Ing Ngarsa Sung Tuladha, Ing Madya Mangun Karsa, Tut Wuri Handayani.

\section{Ing Ngarsa Sung Tuladha}

berarti kepala madrasah mengajari orang lain yang belum punya kompetensi untuk memiliki kompetensi. Dalam hal ini kepala sekolah berusaha mengajari, membimbing para pendidik, karyawan dan peserta didik, namun tidak merasa dirinya merasa orang yang paling tahu. Tetapi lebih banyak mendengar daripada memaksakan kemauannya pada orang lain khususnya bawahan, lebih senang meminta pendapat orang lain agar ikut berpartisipasi untuk memajukan madrasah, dan mampu menjadi teladan dalam berkomitmen untuk memajukan sekolah. Ing Madya Mangun Karsa berarti kepala madrasah bertindak menjadi motivator dan membangkitkan semangat yang menggerakkan hati para komponen warga madrasah untuk melaksanakan tugas. Kepala sekolah berusaha mengajak pendidik yang tidak antusias menjadi antusias, yang tidak memiliki komitmen menjadi komitmen, pendidik yang semula tidak mendukung menjadi mendukung setia mencapai visi, misi, dan tujuan madrasah. Tut Wuri Handayani berarti kepala sekolah berupaya membentuk sinegisitas dengan memiliki kemauan untuk memberdayakan dan memberi peluang kepada warga madrasah untuk berani mengambil inisiatif untuk memajukan madrasah secara bersama-sama (Siswoyo, 2007:123).

Ketiga konsep yang diajarkan oleh Ki Hajar Dewantara tersebut, agar berjalan dengan baik, kepala madrasah MA Darul Ulum Kota Semarang harus menerapkan fungsi-fungsi manajemen dalam mengelola lembaga sehingga lembaga akan mampu mewujudkan tujuan yang telah ditetapkan. Baik dari proses perencanaan, pengorganisasian, pengkoordinasian, pengontrolan, dan pengevaluasian sumber daya untuk mencapai sasaran (goals) secara efektif dan efisien. Efektif berarti bahwa tujuan dapat dicapai sesuai perencanaan, sementara efisien berarti bahwa tugas yang dilaksanakan secara benar, terorganisir sesuai jadwal.

Berangkat dari hal ini maka dalan pengelolaan suatu lembaga tak terkecuali madrasah penerapan fungsifungsi manajemen menjadi keharusan, karena manajemen memegang berbagai peran penting yang menentukan keberhasilan dalam mencapai tujuan yang telah ditetapkan. "Manajemen yang baik haruslah berperan sesuai situasi dan kondisi pada organisasi. Manajemen yang tidak bisa menjalankan peran sesuai tuntutan organisasi dapat membawa kegagalan".

Menurut Stoner, semakin banyak jumlah sumber kekuasaan yang tersedia bagi pemimpin, akan makin besar potensi kepemimpinan yang efektif (Bush \& Coleman, 2012). Pontensi yang berkembang dalam jiwa kepemimpinan nampak pada Gaya pemimpinan transformatif yang diterapkan di MA Darul Ulum Kota Semarang Kepemimpinan transformatif 
ini dalam konsep Ki Hajar Dewantara adalah Ing Ngarsa Sung Tuladha, Ing Madya Mangun Karsa, Tut Wuri Handayani.

\section{Upaya optimalisasi manajemen dalam mewujudkan profesionalitas guru melalui kepemimpinan transformatif di MA Darul Ulum Kota Semarang.}

Upaya optimalisasi dalam meujudkan profesionalitas guru dilakukan oleh kepala sekolah dengan pendekatan kepemimpinan tranformatif. Kepemimpinan transformatif yang dilakukan kepala sekolah meliputi usaha perencanaan, pengorganisasian, penggerakan, dan pengawasan untuk mencapai tujuan yang telah ditetapkan dengan menggunakan potensi yang ada di sekolah. Fungsi menejemen adalah elemen dasar yang tidak bisa dipidahkan dari proses menejemen sebagai acuan dalam melaksanakan kegiatan untuk mencapai tujuan. Adapun unsur dari menejemen terdapat beberapa tahapan yaitu pertama, perencanaan (planning), menentukan segala sesuatu yang akan dibutuhkan di masa mendatang untuk mencapai tujuan. Kedua, pengorganisasian (organizing), suatu proses yang dilakukan untuk menentukan, mengelompokkan, membentuk pola dan sistem kerja sama kelompok untuk mencapai tujuan. Ketiga, pelaksanaan (actuating), suatu tindakan dan usaha yang dilakukan untuk mencapai sasaran perencanaan guna mencapai tujuan. Keempat, evaluasi (controlling), sesuatu yang dilakukan untuk memastikan seluruh kegiatan terlaksana sesuai dengan perencanaan yang telah ditetakan (Istikomah \& Budi, 2021). Beberapa tahapan tersebut dapat dijelaskan sebagai berikut.

\section{a. Planning atau Perencanaan}

Kepala sekolah langkah awal dalam menjalankan kepemimpinan transformatif butuhpenyusunan visi misi. Dalam menyampaikan program mutu madrasah sesuai visi, misi, dan tujuan madrasah MA Darul Ulum Kota Semarang.

\begin{tabular}{|c|c|}
\hline Visi & $\begin{array}{lrr}\text { Terwujudnya } & \text { Insan } & \text { Kreatif, } \\
\text { Mandiri, dan } & \text { Religius } & \text { Berbasis } \\
\text { Teknologi } & \text { dan } & \text { Sains } \\
\text { Berlandaskan } & \text { Ahlu Sunnah Wal } \\
\text { Jama'ah } & & \end{array}$ \\
\hline Misi & 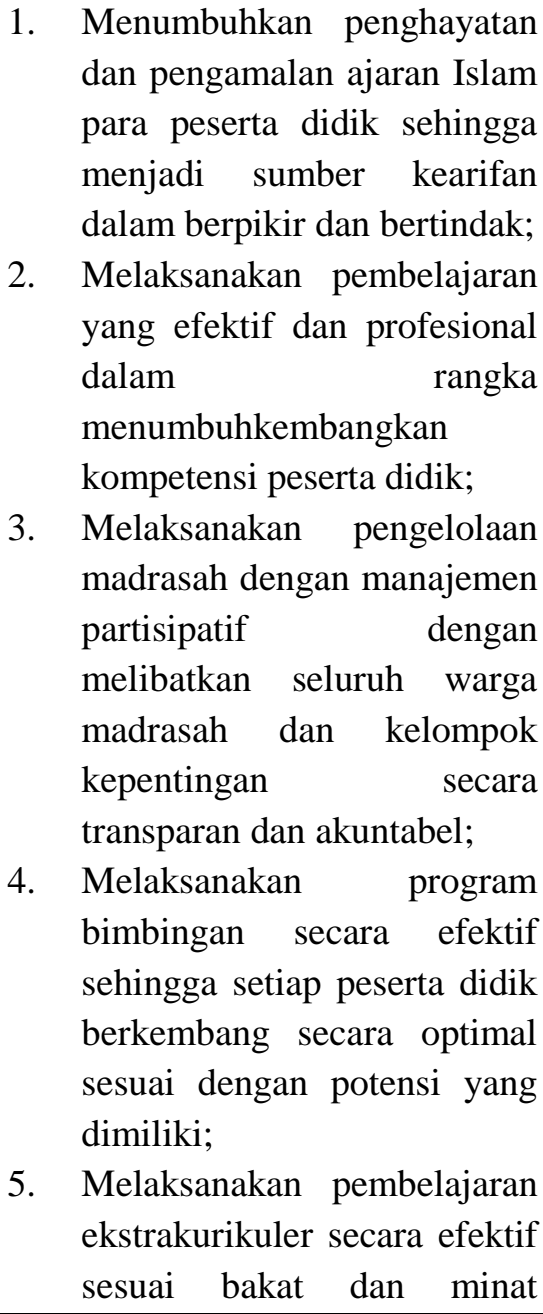 \\
\hline
\end{tabular}




\begin{tabular}{|c|c|}
\hline & $\begin{array}{l}\text { sehingga setiap peserta didik } \\
\text { memiliki keunggulan dalam } \\
\text { berbagai lomba sains, } \\
\text { keagamaan, olah raga, dan } \\
\text { seni; dan } \\
\text { 6. Menumbuhkembangkan } \\
\text { budaya religius, disiplin dan } \\
\text { peduli dalam setiap aktivitas } \\
\text { di lingkungan madrasah. }\end{array}$ \\
\hline Tujuan & $\begin{array}{l}\text { Akademik: } \\
\text { a. Mencapai tingkat } \\
\text { keberhasilan UAMBN } \\
\text { dengan nilai minimal 7,0 dan } \\
\text { ujian nasional minimal rata- } \\
\text { rata 6,0; } \\
\text { b. Mendorong dan } \\
\text { memfasilitasi peserta didik } \\
\text { untuk dapat mencapai } \\
\text { ketuntasan belajar minimal } \\
\text { pada semua mata pelajaran; } \\
\text { Mendorong dan melatih } \\
\text { peserta didik untuk dapat } \\
\text { menjuarai Kompetisi Sains } \\
\text { Madrasah Tingkat Kota } \\
\text { Semarang Tahun 2019. } \\
\text { Non-akademik: tingkat } \\
\text { Melatih peserta didik untuk } \\
\text { terbiasa dan disiplin dalam } \\
\text { menjalankan ibadah shalat } \\
\text { fardhu dan sunah dhuha; } \\
\text { Mengembangkan proses } \\
\text { pembelajaran yang efektif } \\
\text { untuk mencapai tings dik } \\
\text { kompetensi peserta didik } \\
\text { yang baik; untuk } \\
\text { Memfasilitasi peserta didik } \\
\text { untuk mengembangkan bakat } \\
\text { dan minatnya di bidang seni } \\
\text { dan olah raga, sains untuk } \\
\text { dapat mencapai prestasi di } \\
\text { tingkat kota dan provinsi; } \\
\text { Melatih dan mendorong } \\
\text { peserta didik } \\
\text { mengembangkan bakat dan }\end{array}$ \\
\hline
\end{tabular}

\begin{tabular}{l|lr}
\hline & \multicolumn{3}{|c}{ minat di bidang karya ilmiah } \\
remaja sehingga dapat \\
menjadi juara tingkat kota \\
Semarang di Tahun 2019- \\
2023; dan & \\
5. & Membiasakan peserta didik \\
& untuk memiliki sikap \\
& kepedulian sosial dan \\
lingkungan alam, yang \\
diwujudkan dalam pola hidup \\
damai dan bersih di \\
lingkungan madrasah. \\
\hline
\end{tabular}

Visi, misi, dan tujuan yang telah ditentukan kemudian disosialisasikan dengan mendeskripsikan program-program yang akan menjadi target, peningkatan mutu pembelajaran, karakter yang dikembangkan baik dalam intrakulikuler maupun ekstrakulikuler, serta menyampaikan tugas dan kewajibannya masing-masing pihak. Pada tahapan sosialisasi ini melibatkan beberapa unsur, baik yayasan, komite, dan warga sekolah. Dari pihak yayasan yang hadir adalah Prof. Dr. H. Erfan Soebahar, MA.; Prof. Dr. H. Mansur, M.Ag; Dr. Safrudin, M.Ag; K.H. Thohari, S.Ag. Dari pihak Komite yang hadir adalah K.H. Sarjuni, K.H. Ali Said al Hafidz), juga dihadiri oleh pendidik, karyawan, orang tua dan peserta didik.

Langkah lainnya juga dilakukan kepala sekolah dalam sosialsiasi program madrasah, yaitu dengan memasang visi, misi, dan tujuan juga tata tertib di papan informasi dan bahkan di setiap 
ruang kelas sehingga akan bisa dipahami oleh warga sekolah menuju layanan perofesional dalam lembaga pendidikan.

\section{b. Organizing atau Pengorganisasian}

Pada tahap ini kepala madrasah menyampaikan dalam rapat internal madrasah terkait dengan:

1) Struktur organisasi beserta menjelaskan tupoksi yang harus diemban oleh masing-masing pelaku pendidikan;

2) Kepala madrasah membentuk paguyuban wali peserta didik melalui group Watshaap;

3) Memberikan tugas dan wewenang secara penuh kepada masingmasing personil sesuai dengan bidang dan tupoksinya baik guru karyawan sehingga bisa lebih professional dalam melayani, senada dengan paguyuban wali siswa dan komite madrasah; dan

4) Mendelegasikan wewenang.

\section{c. Leading atau Memimpin}

Kepala madrasah mengkomunikasikan harapan-harapan yang tinggi terhadap budaya mutu sekolah sesuai visi, misi, dan tujuan madrasah kepada warga madrasah, seperti:

1) Mengajak semua warga madrasah dan orang tua untuk sama sama menyusun program mutu madrasah;

2) Menjadi narasumber pelatihan internal madrasah untuk meningkatkan kompetensi pendidik secara profesional;

3) Mengarahkan program OSIS yang telah disetujui oleh Waka
Kesiswaan;

4) Kepala madarsah selalu mengajak dan mendorong orang tua dan komite agar ikut membantu penggalian dana, ide gagasan dan sebagainya untuk mewujudkan mutu madrasah;

5) Kepala madrasah berpartisipasi aktif pada setiap kegiatan ikut sehingga warga madrasah menjadi lebih termotivasi, antusias, dan komitmen dalam mewujudkan program madrasah; dan

6) Mengarahkan pendidik untuk melaksanakan pembelajaran inovatif, karyawan bekerja sesuai tupoksinya, komite dan orang tua mendukung program madrasah dan mendelegasikan wewenang sesuai dengan tupoksi.

\section{d. Monitoring atau Pengawasan}

Kepala madrasah mengawasi atau memantau kegiatan-kegitan yang telah diprogramkan dengan mendelegasikan wewenang sesuai dengan tupoksinya apakah sudah sesuai apa belum, dengan cara melakukan ceklist di buku khusus. dan memberi mengevaluasi kegiatan setiap tahunnya bersama seluruh warga madrasah.

\section{e. Evaluating atau evaluasi}

Kepala madrasah melakukan evaluasi setiap bulan pada rapat rutin madarsah yang diadakan pada minggu keempat, dimana rapat rutin ini membahas terkait dengan ketercapaian program baik yang sudah terpenuhi maupun yang belum pada guru serta pelaksana manajemen 
pendidikan di madrasah, serta mencari solusi bersama dengan warga madrasah sebelum ditetapkan kebijakan baru. Selain itu, kepala madrasah juga memberikan reward bagi pihak-pihak yang telah berhasil melaksanakan tugasnya dengan profesional.

Langkah yang ditempuh adalah setiap guru diminta untuk menyampaikan permasalahan yang dialami selama proses pembelajaran, wakil kepala bagian kesiswaan pun diminta untuk menyampaikan terkait dengan prosentase kedisiplinan anak, begitu juga dengan wali kelas serta guru bimbingan konseling.

Adapun penyelesaiannya tidak semuanya ditimpakan kepada kepala madrasah, namun disesuaikan dengan domainnya, seperti, terkait dengan permasalahan pembelajaran yang dijawab guru maka yang menjawab adalah wakil kepala bagian kurikulum, sedangkan domain permasalahan wakil kepala bagian kesiswaan, wali kelas, dan guru bimbingan konseling dijawab oleh kepala madrasah, kemudian ditawarkan kepada forum rapat, apakah disetujui atau tidak. Dengan demikian, keputusan yang diambil dapat diterima serta menjadi tanggung jawab bersama.

\section{PENUTUP}

Gaya pemimpinan transformatif yang diterapkan di MA Darul Ulum Kota Semarang adalah konsep Ki Hajar Dewantara yaitu Ing Ngarsa Sung Tuladha, Ing Madya Mangun Karsa,
Tut Wuri Handayani. Managemen kepemimpinan transformatif dalam upaya peningkatan kualitas kepala sekolah MA Darul Ulum Kota Semarang dalam mengoptimalkan profesionalitas guru meliputi perencanaan (planning), pengorganisasian (organizing), koordinasi (coordinating), dan pengawasan (controlling). Perilaku kepemimpinan trasformatif dalam melaksanakan keterampilan ini memegang peranan yang sangat penting untuk meningkatkan kualitas sekolah. Perilaku kepemimpinan transformatif membawa perilaku yang positif dan mendukung terhadap penerapan manajemen kepala sekolah akan lebih mencapai keberhasilan.

\section{DAFTAR PUSTAKA}

Agus Purwowidodo, Saifudin Zuhri, D. (2020). Implementasi Gaya Kepemimpinan Transformatif dalam Peningkatan Daya Saing Pendidikan(Kajian Multikasus di MI Perwanida Kota Blitar dan SDI Al-Munawir Kabupaten Tulungagung). Ta'allum, 8(1), 309-332. https://doi.org/10.21274/taalum.20 20.8.2.309-332

Aminuddin, M. Y. (2017). Model Kepemimpinan Transformatif (Kajian Kepemimpinan Transformatif di Lembaga Pendidikan Islam). Al Hikmah Jurnal Studi Keislaman, 7(September), 14-32. 
Badeni. (2014). Kepemimpinan dan Perilaku Organisasi. Bandung: Alfabeta.

Bush, T., \& Coleman, M. (2012). Manajemen Mutu Kepemimpinan Pendidikan. Jakarta: Rineka Cipta.

Fadhli, M. (2017). Manajemen Peningkatan Mutu Pendidikan. Jurnal Studi Manajemen Pendidikan, 1(2).

Hermino, A. (2014). Kepemimpinan Pendidikan di Era Globalisasi. Yogyakarta: Parama Publishing.

Istikomah, \& Budi, H. (2021). Manajemen dan Kepemimpinan Pendidikan Islam. Sidoarjo: Nizamia Learning Center.

Karim, M. (2010). Transformasional: di Lembaga Pendidikan Islam. Malang: UIN Maliki Press.

Komsiyah, I. (2016). Kepemimpinan Transformatif Perkembangan dan Implementasinya pada Lembaga Pendidikan. Ta'allum, 4(2), 293316.

Lestari, P. (2017). Kepemimpinan Transformatif dalam Membangun Budaya Kewargaan: Studi Kepemimpinan Ridwan Kamil di
Kota Bandung. INTEGRALISTIK, XXVIII(1), 40-48.

Muhammad, J., Aan, P., \& Khomsun, S. (2015). Analisis Dampak Sosial dan Ekonomi dalam Pembangunan Flyover Jimbor di Kbupaten Sleman. Jurnal Pelita, 10(1).

Muslim, M. (2018). Pemaknaan Min Al-Dhulumat Ila-Nur dalam Usaha Transformatif Lembaga Pendidikan Islam. Jurnal Studi Dan Penelitian Pendidikan Islam, 1(1).

Nengsih, S., Gusfira, R., \& Pratama, R. (2020). Kepemimpinan Transformatif di Lembaga Pendidikan Islam. PRODU: Prokurasi Edukasi Jurnal Manajemen Pendidikan Islam, 2, $38-54$.

Siswoyo, Dwi. (2007). Ilmu Pendidikan. Yogyakarta. Fakultas Ilmu Pendidikan UNY.

Suci, N. M. (2019). The Evolution Of Management Thought. Jurnal Manajemen Dan Bisnis, 1(1).

Wayne, H., \& Miskel, C. G. (2014). Administrasi Pendidikan. Yogyakarta: Pustaka Pelajar. 